\title{
Özel eğitim okul bahçelerinin değerlendirilmesi
}

\author{
Sima POUYA ${ }^{\mathbb{1}}$, Enesnur BAYINDIR ${ }^{(1}$ \\ 1İnönü Üniversitesi, Güzel Sanatlar ve Tasarım Fakültesi, Peyzaj Mimarlı̆̆ı Bölümü, Malatya
}

Alınış tarihi: 20 Ağustos 2020, Kabul tarihi: 20 Nisan 2021

Sorumlu yazar: Enesnur BAYINDIR, e-posta: enesnurbayindir@gmail.com

\section{$\ddot{0} \mathbf{z}$}

Amaç: $\mathrm{Bu}$ çalıșmanın amacl; okul bahçelerinin engelli çocuklar üzerindeki önemine vurgu yaparak, okul bahçesi tasarımında dikkat edilmesi gereken tasarım kriterlerinin tespit edilmesi olmuştur. Sonuç olarak Türkiye'deki özel eğitim okul bahçelerinin mevcut durumu üzerinde durarak bu alanların daha verimli olabilmesi için öneriler getirilmiştir.

Materyal ve Yöntem: Çalışma yapılırken gerekli konularda literatür taraması yapılmıştır, dünyadan okul bahçesi tasarımları incelenmiştir ve elde edilen veriler derlenip ortaya engelsiz okul bahçeleri için tasarım kriterleri sunulmuştur.

Araştırma Bulguları: Okul bahçelerinin toplumun birçok kısmında yer alamayan engelli çocukların gelişimi, topluma katılmaları için önemi büyüktür. Dünyadan okul bahçesi tasarımlarına bakıldığı zaman çocukların gelişimi ve doğayla iletişim kurmaları için belirli kriterler göz önüne alınarak tasarlandıkları ortaya çıkmaktadır.

Sonuç: Türkiye'de ki özel eğitim okul bahçelerinin tasarımlarında engelli çocukların ihtiyaçları göz ardı edilmekte ve gelişimine katkı sağlayacak düzenlemeler yapılmamaktadır. Özel eğitim okul bahçelerinin tasarımlarında ki sorunların çoğu, engelli çocukların engel türleri, ihtiyaç ve gereksinimleri göz önüne alınmadan tasarlanmasından kaynaklanmaktadır. Özel eğitim okul bahçelerini engelli çocukların kullanamaması sorununu ortadan kaldırmak için tasarımcıların engelli çocukları göz önünde tutarak, evrensel tasarım ilkeleri doğrultusunda tasarım yapmaları ve uygulanamaya geçirmeleri gerekmektedir. Devletin özel eğitim okul bahçelerini engelli çocukların kullanımına uygunluğu açısından incelemesi ve gerekli tasarım kriterleri belirlemesi de bu sorunun çözümü için büyük öneme sahiptir. Özel eğitim okul bahçelerinin engelli çocukların gelişimi için öneminin yanı sıra engelli bireylerin hayata tutunması için ailelerine, topluma ve devlete görevler düşmekte, onları ötekileștiren düzenlemeler, davranıșlar, sözler ve tasarımlardan kaçınılmalı onların topluma kazandırılması için herkes elinden geleni yapmalıdır. Engelli çocuklar için okul bahçesi tasarımlarında erişebilirlik ve ulaşabilirlik, ergonomi ve kullanılabilirlik, okul bahçelerinde fiziksel hareketliliği destekleyen mekan ve aktivitelerin tasarlanması, okul bahçelerinde uygulama bahçeleri ve doğa eğitimi, engelli çocukların sosyalleşmelerine yönelik tasarlanan aktiviteler, engelli çocukların farklı duyularına hitap eden tasarlanmış alanlar, bitki seçimi kriterleri göz önünde tutulmalıdır. Çocukların engel türleri ve bu kriterler doğrultusunda onların ihtiyaçlarına cevap verecek, psikolojik, fiziksel ve sosyal anlamda gelişimlerine katkı sağlayacak 'engelsiz okul bahçesi' tasarımları mümkündür.

Anahtar kelimeler: Engelli çocuklar, Okul Bahçesi, Özel Eğitim Okulları, Tasarım

\section{Investigation of gardens of special education school}

\begin{abstract}
Objective: The purpose of this study; to identify the design criteria to be considered in school playground design by emphasizing the importance of school gardens on children with disabilities. As a result, with the focus on the present situation of special education school gardens in Turkey has brought suggestions for these areas to be more efficient
\end{abstract}


Materials and Methods: While conducting the study, a literatüre review was made on the necessary subjects, the designs of school gardens from around the World were examined, and the data obtained were compiled and design criteria for barrier-free school gardens were presented.

Results: School gardens are important for the development of disabled children, who cannot participate in many parts of society, and for their participation in society. Looking at school garden designs from around the world, it becomes clear that they are designed taking into account certain criteria for children's development and communication with nature.

Conclusion: In the design of special education school gardens in Turkey, the needs of children with disabilities are ignored and arrangements are not made to contribute to their development. Many of the problems in the design of special education school gardens are due to the fact that children with disabilities are designed without taking into account the types of obstacles, needs and requirements. In order to eliminate the problem of the inability of disabled children to use special education school gardens, designers must design and implement them in accordance with universal design principles, taking into account children with disabilities. It is also of great importance for the government to examine special education schoolyards in terms of their suitability for the use of children with disabilities and to determine the necessary design criteria for solving this problem. Importance for the development of the school yard special education of children with disabilities, as well as to hold on to the life of individuals with disabilities, their families, society and the role of the state in otekilestiren arrangements, behaviors, words, and designs should be avoided everyone for their reintegration make the best of it. Accessibility in the design of the school playground for children with disabilities and accessibility, ergonomics and usability, venues and activities that support the design of physical activity on school grounds, on school grounds gardens and nature education application, designed for children with disabilities to socialize, activities, designed to appeal to the senses of children with disabilities in different areas, plant selection criteria should be taken into consideration. According to the types of disabilities of children and these criteria, it is possible to design a 'school garden without obstacles' that will respond to their needs and contribute to their development in a psychological, physical and social sense.

Key words: children with disabilities, school garden, Special education school, design

\section{Giriş}

Doğanın doğal çevre değerlerinin (bitki örtüsü, su kaynakları, kuşlar ve diğer canlılar) engelli çocuklarda iyileştirici özelliği görülmektedir. Çocuklar için doğa, günlük yaşamlarında sağlık veren ve iyileştirici bir çevre olarak görülmektedir. Doğa yaşamda deneyim kazanma fiziksel çevremizi algilama ve anlama mekanizmamı olan "insan duyumsal sistemi" için besindir. Eğer duyusal kanallardan biri zarar görmüşse ya da yoksa, diğer kanallar onun boşluğunu dolduracaktır. Çok duyusal ve canlı olan çocukları iyileştiren bahçeler; doğayla etkileşimleri ve sunduğu aktivitelerle çocukların dünyayla ilişki kurdukları araç, hem teşvik hem de teselli bulabildiği özel bir öneme sahiptirler (ADA, 1991).

Çocuklar engelli bireylere karşı olumsuz bir önyargıya sahip olmadıkları gibi engellilik onlar için olağanüstü bir durum oluşturmamaktadır. Çocuklar engellilik durumunu olduğu gibi kabul etmektedir. $\mathrm{Bu}$ yüzden engeli olan-olmayan çocuklar beraber büyüdüklerinde, oynadıklarında veya okula gittiklerinde aralarında ayrım ve sınırlamalar olmamaktadır (Özdemir, 2017).

Engelli çocukların çoğu parklara, çocuk oyun alanlarına, yeşil alanlara vs. gidememektedir. Ulaşım, erişim yönünden sıkıntı yaşadıkları, engelli bireyler göz ardı edilerek tasarlanan yani evrensel tasarım kriterlerine uygun olmayan, insanların etik olmayan sözlerini işittikleri, bu engelli alanlara gidemeyen öğrenciler zamanlarının çoğunu okulda geçirmektedir. $\mathrm{Bu}$ yüzden okul bahçelerinin tasarımları bu engelli öğrenciler için çok büyük öneme sahiptir.

Okul çocukların günlük yaşamlarının büyük bir kısmını geçirdikleri yerdir. Bu yüzden okul çocukların hayatını ve gelişimlerini etkileyen önemli bileşenlerden biridir. Bununla birlikte, dinlenme, hareket, öğrenme ve yaşama mekânı olan okul bahçeleri de, çevreye duyarlı, sağlıklı ve aktif bireylerin yetiştirilmesi için büyük öneme sahip mekânlardır (Pouya ve ark., 2016).

Dünyadaki engelli çocukların okula gitme oranlarına bakıldığında; Namibya'da 5 yaşından büyük engelli çocukların \%38.6'sının hiç okula gitmediği, 
Kanada'da 5 ile 14 yaş arasındaki engelli çocukların \%94'ünün okula devam ettiği, Yeni Zelanda'da ise çocukların \%5'inin özel eğitime gereksinim duydukları belirlenmiștir. Ülkemizde ise genel nüfusta okuma yazma bilmeyenlerin oranı yaklaşık \%13'tür. Bu oran engelli bireylerde yaklaşık \%36, süreğen hastalığı olanlarda ise yaklaşık \%25'dir (Bilsin ve Başbakkal, 2014).

Ülkemizde 1.489 okulda 9.361 özel eğitim sınıfında $145.980 \mathrm{klz}$ ve 252.835 erkek olmak üzere toplam 398.815 engelli öğrenciye 14.043 öğretmen ile örgün eğitim hizmeti verilmektedir (Millî Eğitim İstatistikleri, 2019). Bu Özel Eğitim Okulları akranlarından farklılık gösteren bireylerin fiziksel ve sosyal anlamda gelişimi için önemli rol üstlenmektedir. Bu okullar çocukların toplumsal yaşamın ana akışına katılmalarını, sosyal iletişim kurmalarını, aktif vatandaş olmalarını, kişisel gelişimlerine katkıda bulunmalarına zemin hazırlamaktadır. Bu yüzden Özel Eğitim Okullarının önemi oldukça büyüktür.

Özel eğitimin amacl; özel eğitime ihtiyacı olan bireylerin yetersizlik hissettiği alanların onlar için engele dönüşmesini önlemek, engelli bireylere kendine yetebilecek düzeyde ve toplumla kaynaşmasını, bağımsız ve üretici bireyler olmasını sağlayacak yetenekler kazandırmalarına olanak sağlamaktır (Ergül, Baydık \& Demir, 2013). Bununla birlikte, özel eğitimin tamamen sorunsuz bir yaşam ve kesin iyileșme ile sonuçlanması her zaman mümkün değildir. Sorunları aza indirmek, bireyin öz bakım, temizlik, beslenme ve giyinme gibi temel yaşam yetenekleri edinmesi bile bazen başarı olarak değerlendirilmektedir (Doğan, 2019).

Özel eğitim okullarında verimli öğretim yapılabilmesi için öğrencilerin kişisel ihtiyaçlarını göz önünde tutarak kişiselleştirilmiş eğitim programları oluşturulmalıdır. Kişiselleştirilmiş eğitim programlarının amacı, öğrencilerin eğitsel ihtiyaçlarını belirlemek, bu ihtiyaçları öncelik sırasına dizmek, detaylı incelemeler yaparak öğrencilerin performans düzeyini belirlemek ve performans düzeylerini göre öğretimsel amaçlar yazmaktır (Erol, 2010).

Özel Eğitim Okulları ve bahçeleri çocuklara eğitim vermek dışında aynı zaman da çocukların gerçek hayata katıldığı mekanlardır. Okul ve okul bahçesi tasarımları, planlanmaları çocukların öğrenme kabiliyeti dışında psikolojik, fiziksel, sosyal, duygusal gelişimlerine de olumlu ve olumsuz olarak katkı sağlamaktadır. Çocuğun, okul bahçesinde yaşayarak, oynayarak edindiği deneyimler, okul ve diğer eğitim araçlarından edindiği bilgiler kadar önemlidir (Aksu, Demirel, 2011).

"Sınıf öğretmenim beni okuldan kovmuștu ilkokulda, engelli olduğum için çık dışarı dedi. Öyle kalakaldım. Insanlara göre biz evde oturmaliyı. Mesela ne yapacaksın? diyor dişarı çıkıp, ne yapacaksın okuyup? evinde otur. Niye çalışlyorsun? Bizim bir yaşama hakkımız yokmuş gibi davranıyorlar. Bizimde bir hayat mücadelemiz var tıpkl diğer insanlar gibi..." (Tekin, 2019).

Tekin 2019'da da bireyin ifade ettiği gibi onların hayat mücadelelerine destek çıkacak şekilde tasarılar yapılmalıdır. $\mathrm{Bu}$ bireyler için gerçek hayatla karşılaştıkları, topluma katıldıkları ilk mekanlar olan okul ve bahçelerinin planlamaları oldukça öneme sahiptir. Okul ve bahçeleri işlevsel ve fonksiyonel olarak engelli olan olmayan çocukların bütünleşmesi, kaynaşması ve farksız olması esas alınarak tasarlanmalıdır. Bütün çocuklar için ulaşılabilir, erişilebilir ve sosyal iletişim kurmaları için gerekli alt yapıya sahip planlanmalıdır.

Engellilerin yaşamın akışına katılmalarını önleyen düzenlemelerin, onları toplumsal yaşamdan dışladığı kesindir. Engelli öğrencilerin sosyal hayata katılmalarını sağlayarak kapalı mekanlara hapsolmalarını engellemek, toplum içinde yer almalarını sağlamak bu öğrencilerin okul ve okul bahçelerine erişebilmeleri ve okul ve bahçesini ihtiyaçlarına cevap verecek şekilde kullanmalarıyla mümkündür. $\mathrm{Bu}$ yüzden okul ve okul bahçelerinin planlanması, tasarlanması oldukça büyük bir öneme sahiptir.

Ulaşım, erişim, hareket ve iletişim gibi birçok yönden sıkıntı yaşayan engelli çocukların bu yönlerini geliştirmeleri için hayata katıldıkları ilk mekanlar olan okul bahçelerinin büyük önemi vardır. Özel eğitim okullarının bahçeleri öğrencileri geliştirmek, sosyalleştirmek, iyileştirmek, topluma kazandırmak, hareket ettirmek için tasarlanması gerekirken ülkemizde yetersiz bitkisel düzenleme içeren, oturma birimi az olan, standart görünüşe sahip mekanlar olduğu, çoğu okul bahçesinin otopark olarak da kullanıldığı bir beton ve asfalttan ibarettir. Türkiye'deki Özel Eğitim Okulu Bahçelerine bakıldığı zaman büyük çoğunluğunda mekanlar kurgulanırken düşünülmediği ortaya çıkmaktadır. $\mathrm{Bu}$ yüzden okuldaki bahçeler bireyler için gerekli verimi tam olarak karşılamamaktadır. İhtiyaçlara yönelik etkinlikler, etkinliklere yönelik bahçeler bu bireyler için daha uygun olacaktır. 
Bu çalıșmanın amacl; Türkiye'deki okul bahçelerinin engelli çocuklar üzerindeki önemini açıklayıp ve dünya çapında yapılmıș olan örnek özel eğitim okul bahçelerini inceleyerek, bu bahçelerin tasarım kriterlerini açıklamaktır. Engelli çocuklarında diğer çocuklar gibi okul bahçelerini kullanması gerektiği, bu gereğin 'herkes için tasarım' düşüncesiyle sağlanacağı belirtilmiştir.

\section{Materyal ve Yöntem}

Çalışmada amaç engelli çocuklar için okul bahçelerinin önemini açlklayıp, bu bahçeler için tasarım kriterleri sunmaktır. Çalışma yapılırken gerekli konularda literatür taraması yapılmıștır, dünyadan okul bahçesi tasarımları incelenmiştir ve elde edilen veriler derlenip ortaya engelsiz okul bahçeleri için tasarım kriterleri sunulmuştur.

\section{Okul Bahçelerinin ve Oyunun Önemi}

Türkiye'de ki engelli öğrenciler parklara, çocuk oyun alanlarına, yeşil alanlara vs. gidememektedir. Ulaşım, erişim yönünden sıkıntı yaşadıkları, iyi tasarlanmayan, insanların etik olmayan sözlerini işittikleri, bu engelli alanlara gidemeyen öğrenciler zamanlarının çoğunu okulda geçirmektedir. Bu yüzden okul bahçelerinin tasarımları bu engelli öğrenciler için çok büyük öneme sahiptir.

Okul bahçeleri engelli çocukların psikolojik, fiziksel ve sosyal anlamda gelişimlerine katkı sağlamaktatadır. Bu sebepten okul bahçeleri engelli çocukların ihtiyaçlarına cevap verecek ve gelişimlerine katkı sağlayacak şekilde tasarlanmalı ve okul bahçelerinin engelli çocukların gelişimine sağladığı katkı göz ardı edilmemelidir. Bu bahçelerde çocuklar, oyun oynayarak bir şeyleri öğrenmektedir. Oyun çocuğun biyolojik ve sosyal gereksinimleri nedeni ile, kendiliğinden ortaya çıkan, doğal bir davranış biçimi olarak tanımlanır. Çocuk oyun aracılığıyla sosyalleşir, ekipte yer almayı ve uyum sağlamayı öğrenir. Duygu ve düşüncelerini oyun aracılığıyla aktarır, iç dünyasını tanır ve denetleyebilir (Yavuzer, 1993).Çocuk oyun alanları çocuğun oyunlar aracılığıyla içindekileri anlattığı yerlerdir bu yüzden bu çocuk oyun alanları aynı zamanda tedavi edici ve iyileştirici mekan olarak da nitelendirilir (Dönmez, 1992).

Doğa, çocukların psikolojik ve fiziksel gelişimleri için oldukça önemlidir. Doğal alanlar çocukların yaratıcılıklarının gelişmesine katkı sağlar. İskandinav araștırmacılar, doğal donatılarla tasarlanmış, bitkilendirme çeşitliliğinin yoğun olduğu oyun alanlarında oynayan çocuklarda konsantrasyon, motor becerileri ve sosyal aktivitelerinin daha üst seviyede olduğunu görülmüştür. Amerika Birleşik Devletleri'nde yapılan bir araștırmada, doğal donatılarla tasarlanan oyun alanlarında ki oyun faaliyetlerinin, dikkat bozukluğu olan çocuklarda olumlu davranış değişikliklerine neden olduğu tespit edilmiştir. Doğal alanlardaki çocuk bahçelerinin, özellikle konsantrasyon güçlüğü çeken çocuklarda, odaklanma becerilerini geliştirdiği ve yardım ettiği bildirilmektedir (Uslu, Shakouri, 2012).

Bütün çocuklar, oyun oynamaktan haz alırlar, bu nedenle engelli çocukları oyun aracılığıyla eğitmek ve gelişimlerine katkı sağlamak mümkündür. Oyunun engelli çocukların gelişimine yararlı olabilmesi için çevrenin zenginleştirilmesi ve iyi düzenlenmesi gerekmektedir (MEB, 2012).

\section{Özel Eğitim}

"Özel eğitim", özel eğitim gerektiren bireylerin eğitim gereksinimlerini karşılamak için özel olarak yetiştirilmiş personel, geliştirilmiş eğitim programları ve yöntemleri ile onların özür ve özelliklerine uygun ortamlarda sürdürülen eğitimi ifade eder (Resmi Gazete, 1997). Normal çocukların eğitim hizmetlerindekine ek olarak bir takım özel hizmet ve önlemleri gerektiren çocuklara "özel eğitime muhtaç çocuklar" denir. Beden, zihin, duygusal ve sosyal gelişim özellikleri yönünde normal çocukların gelişim ve özelliklerinden ayrılan çocukların eğitim ve öğretim işlerini kapsayan çalışmalar özel eğitimdir (Özsoy, Özyürek, Eripek, 1996).Türkiye'de okulların normal öğrenciler göz önünde tutularak tasarlanması, engelli öğrencilerin için ciddi sınırlamalar oluşturmaktadır (Akçamete, 1998).

"Özel eğitim gerektiren birey", çeşitli nedenlerle, bireysel özellikleri ve eğitim yeterlilikleri açısından akranlarından beklenilen düzeyden anlamlı farklılık gösteren bireyi ifade eder (Çizelge 1) (Resmi Gazete, 1997).

\section{Dünyada Özel Eğitim Okullarının Okul Bahçeleri}

Dünyadaki Özel Eğitim Okullarının bahçelerine bakıldığı zaman belirli tasarım kriterlerinden yola çıkarak hayat kazandığı görülmektedir. Örneklere bakıldığı zaman öncelikle engelli çocukların gelişimleri için açık alanlara ihtiyaç duyduğu bilinciyle okul bahçeleri tasarlanmıştır. Her türden engele sahip birey için alan içindeki ulaşım ve erişim kriterleri düşünülmekte ve mekanlar ona 
göre tasarlanmaktadır. Engelli öğrencilere bu okul bahçelerinde sebze ve meyve yetiştirilmektedir ve bu sayede onların beceriler kazanması, sosyal ilișkiler kurması,kendilerine güvenlerinin artması sağlanmaktadır (Clark, 2019).

Okul bahçelerinde, temelde öğrencilerin farklı öğrenme etkinlikleri için kullanabileceği sakin alanlar oluşturulmaktadır. Duyusal bahçeler, iyileştirme bahçeleri kurgulanarak bu alanlarda çocukların engel türlerine göre gelişimlerine katkı sağlamak hedeflenmektedir.
Dünyadaki bu okul bahçeleri incelendiği zaman belirli birimlerden oluştuğu görülmektedir. Bunlardan bazıları; okul için güçlü bir görsel unsur ve yönlendirme noktalar,sessiz bir oturma/dinlenme alanı, açık hava öğretme ve öğrenme alanı, öğle vakti oturma alanı, personel ve ebeveynler için bir oturma ve toplantı yeri, oyun alanları, bitki yetiștirme alanları,doğa eğitimi verilen alanlar,iç/dış mekan sosyal toplantıları ve işlevleri, hareket eden öğrenciler ve personel için bir dolaşım yoludur (URL 2).

Çizelge 1. Özel eğitim gerektiren bireyler (Özel Eğitim hizmetleri yönetmeliği, rehberlik ve psikolojik danışma hizmetleri yönetmeliği, özürlü bireylere uygulanacak destek eğitim programları ve eğitim giderlerinin karşılanmasına dair yönetmelik) (Öztürk, 2012).

\begin{tabular}{|c|c|}
\hline $\begin{array}{l}\text { Birden fazla yetersizliği olan } \\
\text { birey }\end{array}$ & rden fazla alanda görülen yetersizlik nedeniyle özel eğitim hizmetine ihtiyacı olan birey. \\
\hline Engelli & $\begin{array}{l}\text { oğuștan veya sonradan herhangi bir hastalı veya kaza sonucu bedensel, zihinsel, ruhsal, } \\
\text { uygusal ve sosyal yetilerini çeșitli derecelerde kaybetmiş olan birey. }\end{array}$ \\
\hline Özürlü birey & $\begin{array}{l}\text { Sağlık kurulu raporuyla asgari \%20 özürlü olduğu bilinen, özel eğitim kurulları tarafından destek } \\
\text { eğitimi almaları uygun görülen bireyler. }\end{array}$ \\
\hline $\begin{array}{l}\text { Dil ve konuşma güçlüğü olan } \\
\text { birey }\end{array}$ & $\begin{array}{l}\text { Dili kullanma, konuşmayı edinme ve iletişimdeki güçlük nedeniyle özel eğitim ve destek eğitim } \\
\text { hizmetine ihtiyacı olan birey. }\end{array}$ \\
\hline $\begin{array}{l}\text { Dikkat eksikliği ve } \\
\text { hiperaktivite bozukluğu olan } \\
\text { birey }\end{array}$ & $\begin{array}{l}\text { Yaşına ve gelişim seviyesine uygun olmayan dikkat eksikliği, aşırı hareketlilik, hiperaktivite ve } \\
\text { dürtüsellik belirtilerini en az iki ortamda ve altı ay süreyle gösteren, bu özellikleri yedi yaşından } \\
\text { önce ortaya çıkan, özel eğitim hizmetine ihtiyacı olan. }\end{array}$ \\
\hline $\begin{array}{l}\text { Duygusal ve davranış } \\
\text { bozukluğu olan birey }\end{array}$ & $\begin{array}{l}\text { Iaşına uygun olmayan sosyal ve kültürel normlardan farklı duygusal tepki ve davranışlar göstermesi } \\
\text { eedeniyle özel eğitim ve destek eğitim hizmetine ihtiyacı olan birey. }\end{array}$ \\
\hline Görme engelli birey & $\begin{array}{l}\text { Tek veya iki gözünde görme bozukluğu olanlar, göz protezi kullananlar, göz tansiyonu, renk } \\
\text { körlüğ̈̈, katarakt, gece körlüğü olan bireyler. }\end{array}$ \\
\hline İșitme engelli birey & Bir veya iki kulağı hiç işitmeyen veya az işiten veya ancak işitme cihazı ile duyabilen kişis \\
\hline $\begin{array}{l}\text { Ortopedik yetersizliği olan } \\
\text { birey }\end{array}$ & as ve iskelet sisteminde yetersizlik, eksiklik ve fonksiyon kaybı olan kişidir. \\
\hline Otistik birey & $\begin{array}{l}\text { Sosyal etkileşim, ilgi ve etkinliklerdeki sınırlılı̆̆ı erken çocukluk döneminde ortaya çıkan ve bu } \\
\text { özellikleriyle özel eğitim hizmetine ihtiyacı olan birey. }\end{array}$ \\
\hline Öğrenme güçlüğü olan birey & $\begin{array}{l}\text { Dinleme, konuşma, okuma, yazma, heceleme, da matematiksel işlemleri yapma güçlüğü nedeniyle } \\
\text { özel eğitim hizmetine ihtiyacı olan birey. }\end{array}$ \\
\hline Serebral palsili birey & $\begin{array}{l}\text { Beyin hasarının neden olduğu kas ve sinir sistemi bozukluklarına bağlı motor becerilerde } \\
\text { yetersizliğinden dolayı özel eğitim hizmetine ihtiyacı olan birey. }\end{array}$ \\
\hline Süreğen hastalığı olan birey & $\begin{array}{l}\text { Sürekli ya da uzun süreli bakım ve tedavi gerektiren hastalığı nedeniyle özel eğitim hizmetine } \\
\text { ihtiyacı olan birey. }\end{array}$ \\
\hline Üstün yetenekli birey & $\begin{array}{l}\text { Zekâ, yaratıcıllk, sanat, spor, liderlik kapasitesi veya özel akademik alanlarda akranlarına göre } \\
\text { yüksek düzeyde performans gösteren birey. }\end{array}$ \\
\hline $\begin{array}{l}\text { Zihinsel yetersizliği olan } \\
\text { birey }\end{array}$ & $\begin{array}{l}\text { Çeșitli derecelerde zihinsel yetersizliği olan kişidir. Zeka geriliği olanlar, down sendromu, } \\
\text { fenilketonüri (zeka geriliğine yol açmışsa) bu gruba girer. }\end{array}$ \\
\hline
\end{tabular}

\section{Dünyadan Örnekler}

\section{Horsham Özel Okulu, İngiltere}

Horsham Özel Okulu'ndaki Duyu Avlusu, okul manzarası ve açık hava oyun alanları, özel okul personeli ile yakın ilişki ve istişareden sonra tasarlanmıştır. Duyuları harekete geçiren, eğiten ve uyandıran manzara deneyimleri yaratmak istenmiştir. Her şeyden önce, alan, çeşitli engelleri olan çocukların ve özellikle otizm spektrumundaki çocuklar için özel ihtiyaçlarını karşılamak için son derece duyusal bir alan sağlamak üzere tasarlanmıștır. Tasarım çözümleri, otizm 
spektrumundaki çocuklar da dahil olmak üzere, çeşitli fiziksel ve entelektüel yetenekleri, bireysel özel ihtiyaçları, değişen sosyal becerileri ve duyusal entegrasyon seviyeleri ile çocukları meşgul ettirmek için yapılmıştır. Okulda yapılan duyusal avluya birçok işlev yüklenmiştir. Bunlar:okul için güçlü bir görsel unsur ve yönlendirme noktası sessiz bir oturma/dinlenme alanı,bir açık hava öğretme ve öğrenme alanı,öğle vakti oturma alanı,personel ve ebeveynler için bir oturma ve toplantı yeri,iç/dış mekan sosyal toplantıları ve işlevleri, iç mekanlar arasında hareket eden öğrenciler ve personel için bir dolaşım yoludur (Şekil 1) (Anonim, 2014).

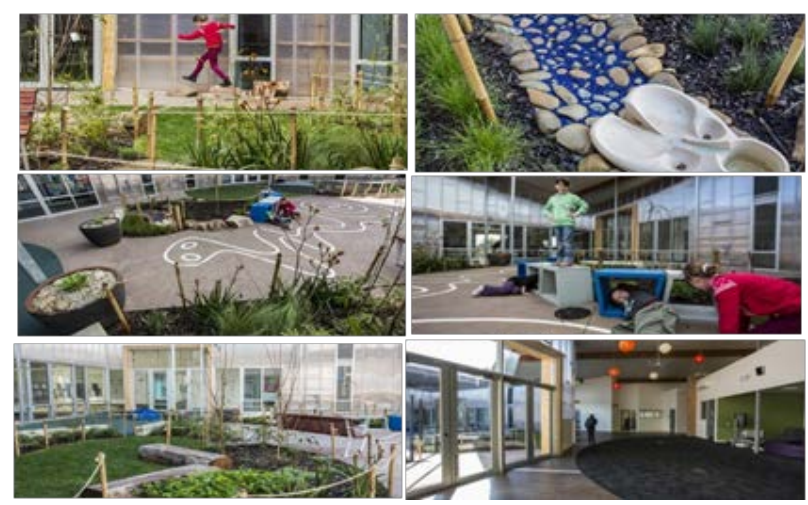

Şekil1. Horsham Özel Okulu (Hıckey, 2014)

Alan, avlunun farklı bölümlerinde farklı faaliyetlerin gerçekleşebileceği şekilde düzenlenmiştir. Çocukların davranışları üzerinde belirgin bir etkiye sahip olduğu gösterilen sakinleştirici bir etki sağlamak için tasarlanmıştır. Dokunsal ve heykelsi unsurlar, çeşitli dokular, yüzeyler ve malzemeler, su, çok çeşitli duyusal dikim, yüksek detay seviyeleri ve çocukların sıkıştırmasına izin veren basınç direkleri gibi bazı özel özellikler ile çeşitli duyusal deneyimler sunulmuştur (Anonim 2014).

Doku, renk, koku ve seslerin yanı sıra mekansal çeșitlilik, termal özellikler ve hareket ile sanatsal ve güzel mekanlar yaratmak için terapistler ve diğer personel ile birlikte çalışılmıştır. Çocukların güçlü yanlarına dayanan ve personelle iletişim, öğrenme ve sosyal becerilerin geliștirilmesine yardımcı olan bir ortam sağlayan eğlenceli, öğrencileri meşgul eden bir alan tasarlamayı amaçlamışlardır.

Temelde okulun bahçesindeki avluda bir duyusal bahçe kurulmuştur.Öğrencilerin farklı etkinlikler için kullanabilecekleri,ağaç, meyve, sebze dikecekleri, meşgul olup kendilerine uğraş çıkarabilecekleri, iletişim becerilerini geliştirip eğlenebilecekleri sakin bir bahçe yapılmıştır (Hıckey, 2014).

\section{Hokksund Ortaokulu, Hokksund, Norveç}

Tasarım, hem okul saatleri içinde hem de sonrasında farklı ihtiyaç ve becerilere sahip çocuklar ve gençler için çekici, çeșitli ve heyecan verici etkinlikler yaratmaya vurgu yapmaktadır. Yeşil kısım, yoğun kullanım nedeniyle suni çim ile kaplıdır, dinlenme yerleri, top oynamak için kapalı alan, paten/bisiklet parkı, kum voleybolu ve güç-dengeleme zorlukları gibi alanlar bahçede yer almaktadır (Şekil 2). Parlak turuncu kauçuk asfaltta bir oturma konstrüksiyonu okul bahçesinde merkezi bir konumda yer almaktadır. Uzun şekli ve yerleşimi ile inşaat, hem açlk bir sınıf hem de okul bahçesinin yeşil kısmındaki etkinlikler için bir tribün olarak işlev görmektedir. Kullanıcılar oturmayı, uzanmayı, seyirci olmayl, öğrenmeyi veya sadece öğle yemeği yemeyi seçebilmektedir (Şekil 3). Bu bahçe alanında yer yer farklı renk ve malzemeler uygulanmıştır ve çocukların engel türlerine göre vurgu ve yönlendirici elemanlar olarak kullanılmaktadır. Okul bahçesinde açık sınıf bulunmaktadır ve parlak turuncu kauçuk asfalttan yapılmıştır. Bu açık sınıflar çocukların gelişimi ve doğayla buluşmalara için önemlidir. Alan mevcut büyük ağaçlarla çevrilidir. Steril kiraz ağaçları, turuncu oturma elemanı ile birlikte yapılmıştır. Açı alan herkes için erişilebilirlik gereksinimlerine uyarlanmıştır ve engelliler için tüm aktiviteler mevcuttur. Asansör çatı terasına erişim sağlamaktadır. Yürüyüş $\quad$ yolları 1:20 eğimi aşmamaktadır. Otobüs durağından ana girişe kadar görsel bir kılavuz çizgi vardır (Anonim, 2017).

Bahçede yer alan bölümlerin tümü engelli bireylerin ulaşım ve erişim yönünden sıkıntı yaşamayacağı şekilde tasarlanmıştır. Okul bahçesinde ders oyun ve birçok aktivite alanı oluşturulmuştur.

\section{JP Lord Okulu, Omaha}

JP Lord School, öğrencilerin eğitim, tıbbi ve duyusal ihtiyaçlarını destekleyen bir ortamda, 5-21 yaşları arasında birden fazla engelli öğrencilere hizmet veren Çok Engelliler Programı'na ev sahipliği yapmaktadır. Öğrencilerinin kırılgan durumu nedeniyle, JP Lord'daki eğitim süreç tıbbi bakımlarıyla iç içedir (Şekil 4) (Darland, 2018).

Tasarımda, doğal gün ışığı ve parlak, canlı renklere sahip geniş açık odalar kurgulanmıştır. Bu öğrenciler kapsamlı uyarım ve özel katılım yöntemleri gerektirmektedir. 


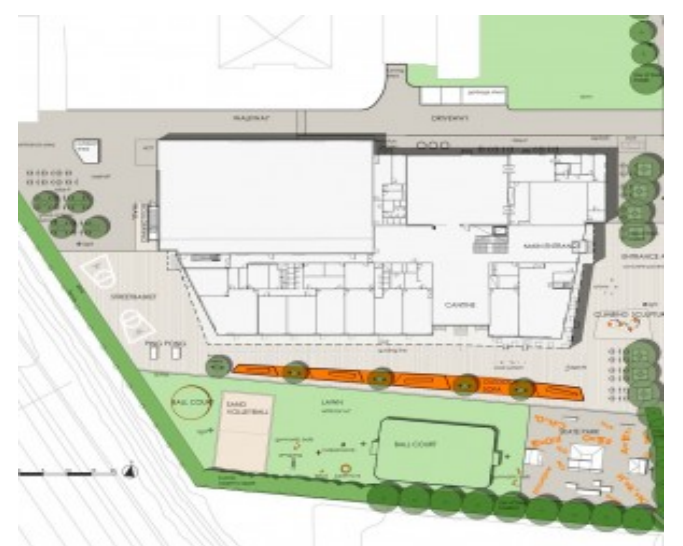

Şekil 2. Hokksund Ortaokulu (Anonim, 2017)

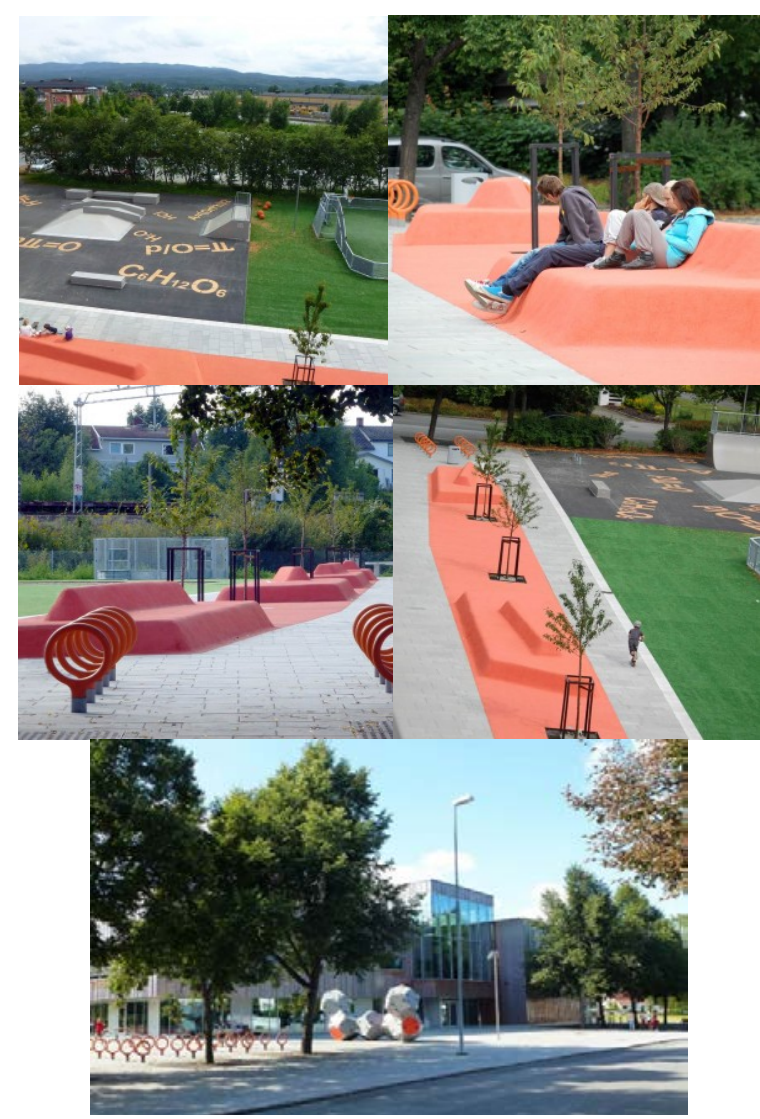

Şekil 3. Hokksund Ortaokulu (Anonim, 2017)

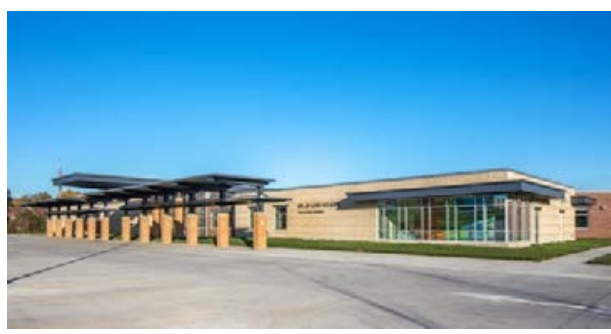

Şekil 4. JP Lord Okulu (BCDM, 2018)
Tasarım, öğrencileri etkileşime teşvik edecek şekilde uyarlanabilen "duyusal bölgeler" ve "duyusal odalar" oluşturmuştur (BCDM, 2018). 45.000 metrekarelik okulda engelli erişilebilir kolidorlar ve sınıflar, çoklu duyusal unsurlar, terapi havuzu ve hareketlilik cihazları bulunmaktadır (Şekil 5). Okul tasarlanırken ebveynler, personel ve özel eğitim uzmanları da tasarıma dahil edilmiş onların fikirlerine yer verilmiştir. Tasarımdaki her öğe, öğrencilerin benzersiz ihtiyaçları göz önünde bulundurularak düşünceli bir şekilde seçilmiştir (Darland, 2018).

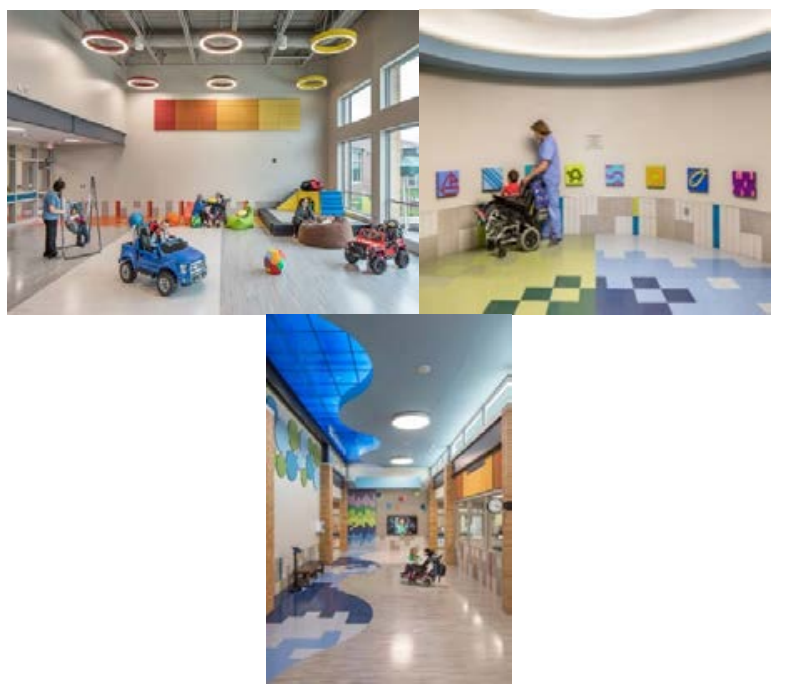

Şekil 5. JP Lord Okulu (BCDM, 2018)

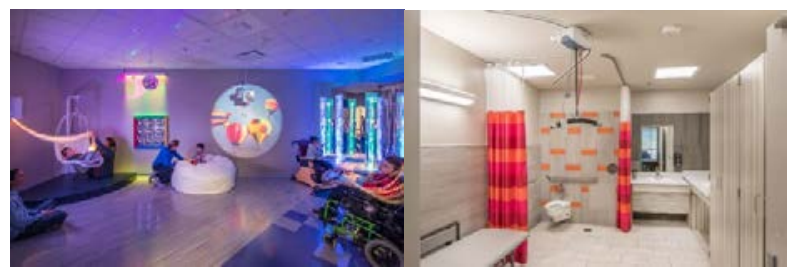

Şekil 6. JP Lord Okulu (BCDM, 2018)

Tasarımına bakıldığı zaman okul parlak renkler, desenler ve değişik materyallerle kaplanmıștır. Bina girişinde gölgelik yapılarak öğrencilerin giriş çıkışları konforlu hale getirilmiş ve hava almaları sağlanmıştır. Büyük pencerelere sahip 8 sınıf yapılmış ve bu sınıflar ağaçları ve gökyüzünü görecek şekilde tasarlanmıştır. Renkli tekerlekli sandalyeler için geniş kolidorlar, patikalar boyunca ışıklar, tavanda pırıltılı yıldızlar ve çocukların dokunup, hissetmeleri için dokulu duvarlar tasarlanmıştır. Çoklu duyulara sahip duyusal odalar tasarlanmış öğrencilerin rahatlaması, etkileşim kurması ve eğlenmesi amaçlanmıştır(Şekil 6). Uyarlanabilir çok amaçlı hareket etmelerine yönelik 
yardımcı ekipmanlar düzenlenmiştir. Ayarlanabilir zemine sahip terapi havuzu yapılmış ve havuza özelleştirilebilir havuz derinliği yapılmış. Kafeterya, medya merkezi, özel sanat odaları, müzik odaları tasarlanmıştır. Hasta asansörleri kullanılmış ve personelin öğrenci transferi yaparken rahat çalışması hedef alınmıştır. Okulun içinde uygulanan tasarım kriterleri aynı zaman da okul bahçesi tasarımı için de referans niteliğindedir. Aynı tasarım kriterleri göz önüne alınarak engelli çocuklar için okul bahçeleri kurgusu da yapilabilmektedir (Darland, 2018).

\section{Özel Eğitim Okul Bahçelerinin Türkiye'deki Durumu}

Türkiye'de ki engelli öğrenciler parklara, çocuk oyun alanlarına, yeşil alanlara vs. gidememektedir. Ulaşım, erişim yönünden sıkıntı yaşadıkları, iyi tasarlanmayan, insanların etik olmayan sözlerini işittikleri, bu engelli alanlara gidemeyen öğrenciler zamanlarının çoğunu okulda geçirmektedir. $\mathrm{Bu}$ yüzden okul bahçelerinin tasarımları bu engelli öğrenciler için çok büyük öneme sahiptir. Fakat okul bahçeleri engellilerin kullanımına uygun olarak tasarlanmamaktadır. Bu durumda engelli çocukların gelecekleri için ciddi bir sorun teşkil etmektedir.

Özel eğitim okullarının bahçeleri öğrencileri geliştirmek, sosyalleştirmek, iyileştirmek, topluma kazandırmak, hareket ettirmek için tasarlanması gerekirken ülkemizde yetersiz bitkisel düzenleme içeren, oturma birimi az olan, standart görünüşe sahip mekanlar olduğu, çoğu okul bahçesinin otopark olarak da kullanıldığı bir beton ve asfalttan ibarettir.

Türkiye'deki Özel Eğitim Okulu Bahçelerine bakıldığı zaman büyük çoğunluğunda mekanlar kurgulanırken düşünülmediği ortaya çıkmaktadır. $\mathrm{Bu}$ yüzden okuldaki bahçeler bireyler için gerekli verimi tam olarak karşılamamaktadır. İhtiyaçlara yönelik etkinlikler, etkinliklere yönelik bahçeler bu bireyler için daha uygun olacaktır.

\section{Okul Bahçelerinin Tasarımında Dikkat Edilmesi Gereken Konular}

Engelli bireylerin özel ihtiyaçları olsa da kentsel yaşama dahil olma ihtiyaçları engelli olmayan bireylerinkiyle çok benzemektedir. Engelli bireylerin de ötekileştirilmeden ulaşım hizmetlerinden aynı şekilde faydalanarak her birey gibi kullanabilmeleri gerekmektedir (Şat, Göner, 2017).
Engelliler için yasa olarak garanti altına alınmış hakların kullanılmasında bile engellinin bulunduğu kentin kaynak ve imkânlarına erişimin sağlanma oranı belirleyicidir (Bezmez, Yardımcl, 2010). Erişilebilirlik bir yerleşim yerine ya da bir yerleşim yerinin sunduğu kamusal hizmetlere erişme olanağı, varış kolaylığıdır (Keleş, 1998). Erişilebilirliğin önemi, kentte, binalar ve dış mekânlarda ulaşılabilirlik olanaklarının olması, herkesin toplumdan eşit faydalanmasını sağlamasından doğar (Sungur Ergenoğlu, 2013).

Ulaşılabilirlik, yapılandırılmış çevrenin temel özelliğidir. Yapılandırılmış çevrede ulaşlabilirliğin sağlanmasının, engellilerin kent hayatına katılmalarına olduğu kadar çevre faktörlerinden kaynaklanan yeti kayıplarıyla karşılaşmalarını önlemesine katkısı da bulunmaktadır (Şat, Göner, 2017).

Engelli çocuklar kent içinde ki birçok alana erişim, ulaşım yönünden sıkıntılar yaşamaktadır. $\mathrm{Bu}$ çocuklar ulaşmaları engellenen parklara, açık yeşil alanlara, meydanlara gidemedikleri için zamanlarının çoğunu geçirdikleri okul bahçeleri onların gelişimi için çok büyük öneme sahiptir. Okul bahçelerinin engelli bireyler tarafından da kullanılabilmesi için alan içinde erişilebilirlik, ulaşılabilirlik kriterlerine uygun tasarımlar yapılmalıdır. Engelli bireyler de okul bahçelerinde istedikleri her alana ergonomik bir șekilde erişebilmeli ve ulaşabilmeli, bir şeyleri başarmanın, tek başına yapabilmenin psikolojik olarak olumlu gelişimlerini hissetmelidirler.

\section{Ergonomi ve Kullanılabilirlik}

Okul bahçesinde donatı elemanları engelli çocukların engelleri ve ergonomik ölçüleri dikkate alınarak ölçülendirilmelidir. Donatı elemanlarının malzemeleri çocuklara zarar verici nitelikte olmamalıdır (Pouya ve ark., 2016). Kullanılan donatı elemanları doğal ve canlı malzemelerden olmalıdır.

Yükseltilmiş çiçek veya bitki yatakları kullanılmalıdır. Örneğin tekerlekli sandalye kullanıcısının bitki ile temasını sağlaması, yetiştirebilmesi için en az $120 \mathrm{~cm}$ genişlikte bir yaya yolu üzerinde; yükseltilmiş çiçek kasası yerden en az $80 \mathrm{~cm}$ olmalıdır. Koltuk değneği kullanan bir kullanıcı için çiçek kasası yerden 85-90 cm yükseklikte olmalıdır (Uslu, 2012).

Bahçedeki yürüme yoluna düşen dallar, yere dökülen yaprakları kaygan yüzeyler ve kirlilik oluşturacak türler, dikenli zehirli ve kaygan meyveler üreten 
türler yürüme yollarında tehlike oluşturabileceği için dikkatli kullanılmaları gerekir (Koca, 2010). Yaya yollarına uzayan dallar özellikle görme engelliler için tehlikeli oluşturmaktadır. Düzenli bakım ve budama yapılmalı, yaya geçişine engel olmayacak şekilde yaya yollarından yeterli uzaklığa dikilmelidir (Koca, 2010).

Mevsim geçişlerini hissettiren bitkisel tasarımlar ve bilgilendirici bitki tanıtım tabelalarının kullanımı da sembollerle tanıtım kapsamında önemlidir. Odak noktalarında ve yönlendirmede; kuş yuvaları, su ses, rüzgar çanı vb. elemanlar mekanı tanımlamaktadır (Uslu ve ark., 2017).

Engelli bireylerin, engel türlerine göre ergonomik ölçüler göz önüne alarak tasarımlar yapılmalıdır. Bu kriterler göz önüne almadan yapılan tasarımlar kullanılabilir ve doğru tasarımlar değildir.

$\begin{array}{lccc}\text { Okul Bahçelerinde } & \text { Fiziksel } & \text { Hareketliliği } \\ \text { Destekleyen } & \text { Mekan } & \text { ve } & \text { Aktivitelerin } \\ \text { Tasarlanması } & & & \end{array}$

Engelli çocukların okul bahçelerinde oyun ve iyileștirme mekânları beraber tasarlanmalıdır. Öğrencilerin oyun oynayıp, hareket ettikleri bu mekanlar ve aktiviteler gelişimlerinde büyük öneme sahiptir. Örneğin doğal donatılarla çocukların engellerine göre düzenlenmiş tepecikler ve çukurlar farklı aktivitelere imkan ve hareket etmelerini sağlarken aynı zamanda da çocukların yaratıcılıklarını arttırır (Pouya ve ark., 2017).

Okul bahçeleri engelli öğrencilerin engel türlerine göre fiziksel hareketliliğini sağlayacak şekilde tasarlanmalıdır. $\mathrm{Bu}$ sayede öğrencilerin kasları, fiziksel hareketlilik becerileri gelișmekte bu da öğrencilere psikolojik ve fiziksel olarak tatmin ve katkı sağlamaktadır.

\section{Okul Bahçelerinde Uygulama Bahçeleri ve Doğa Eğitimi}

Okul bahçelerinde engelliler için uygulama bahçeleri ve doğa eğitimi oldukça büyük öneme sahiptir. $\mathrm{Bu}$ uygulamalar ve eğitim engelli çocukların gelişimi için önemli etkenlerdendir.

Engelli çocuklar için okul bahçeleri farklı doğal oluşumların bulunduğu, merak uyandırıcı sıkıştırılmış doğa etkisi yaratan mekânlar olmalıdır. Bu nedenle okul bahçesinin engelli çocukların temel ihtiyaçlarını karşılaması dışında doğayla uyumlu çocukların engellerine yönelik terapi bahçeleri ve uygulama bahçeleri barındırmalıdır (Pouya ve ark., 2017).
Sıkıştırılmış doğal mekanlar çocukların merakını arttırmada yapay çevreye göre daha fazla tercih edilmektedir. Çocuklar için bahçeler, korunmak için sığındıkları doğal bir liman niteliğindedir.

Uygulama bahçeleri öğretmen ve öğrencileri dört duvar arasındaki ortamdan azat eder; öğretim ve eğitimi yapmacıklıktan, kitaplara kapanmaktan, ezbercilikçi eğitimden uzaklaştırır. Uygulama bahçeleri çocukların tabiatla mücadelele kabiyetlerini yükseltir, tabiatı sevdirir ve çocukların araştırma meraklarını uyandırır. Çocuklar bitkileri oyun materyali olarak kullanıp yaratıcılıklarını ortaya koyabilirler. Okul bahçesinin bitkisel tasarımına estetik ve işlevsel olarak katkı sağlayabilecek alanlar; mevsimlik süs bitkileri, şifalı ve aromatik bitkiler, koku bahçeleri şeklinde ekim ve dikim alanlarıdır.

\section{Engelli Çocukların Sosyalleşmelerine Yönelik Tasarlanan Aktiviteler}

Engelli çocukların sosyalleşmeleri, iletişim becerilerini geliştirmeleri, arkadaş edinmeleri için için önemli araçlardan biri oyundur.

Çocuk oyun alanlarının çocuğun psikolojik ve fiziksel gelişimine yardım eder, çocuğun çevreyi tanımasına sağlar, çocuğun dikkat gücünü arttırır, çocuğun sorumluluk duygusunu geliştirir, sosyalleştirir, çocuğun toplum içindeki girişkenliğini arttırır (Pehlivan, 2005).

Engelli çocukların sosyalleşmeleri, iletişim becerilerini geliștirmeleri, arkadaș edinmeleri için için önemli araçlardan diğerleri uygulama bahçeleri, doğa eğitimi, hareketliliklerini destekleyen erişilebilir ve ergonomik mekanlar yapılmasıdır. Bahsedilen tasarım kriterlerinin uygulanması sayesinde çocuklar her alana ergonomik bir şekilde erişebilir ve kullanabilir, bu da engelli çocukların iletişim kurmasını, sosyalleşmesini sağlamaktadır.

Engelsiz 'herkes için tasarım' ilkeleri altında tasarlanan okul bahçelerinde kurgulanacak her türlü aktivite engelli çocukların sosyalleşmesi için gerekli alt yapıya sahip mekanlar sunacaktır.

\section{Engelli Çocukların Farklı Duyularına Hitap Eden Tasarlanmış Alanlar}

Çocukların engel türlerine yönelik doğal ortamlar oluşturulmalı ve donatılar kullanılmalıdır. $\mathrm{Bu}$ amaçla bahçeler çocukların duyma, görme, koklama ve dokunma duyularıla mekan farklarını algılayacağı şekilde tasarlanabilir. Duyma duyusu için hareket edip ses çlkartan bitkiler dokunma duyusu için geniş ve dokulu yapraklı bitkiler, 
koklama duyusu için güzel kokulu bitkiler; görme duyusu için kırmızı, turuncu ve sarı renkli çiçekli bitki grupları kullanılmalıdır. Farklı sesleri kullanarak (su sesi, rüzgâr sesi gibi) çocuklar üzerinde duyusal uyarım ve yönlendirme sağlanabilir (Pouya ve ark., 2017).

Mevsim geçişlerini hissettiren bitkisel tasarımlar ve bilgilendirici bitki tanıtım tabelalarının kullanımı da sembollerle tanıtım kapsamında önemlidir. Odak noktalarında ve yönlendirmede; kuş yuvaları, su ses, rüzgar çanı vb. elemanlar mekanı tanımlamaktadır (Uslu ve ark., 2017).

\section{Bitki Seçimi}

Çocuk oyun alanlarında bitkisel elamanlar hem fonksiyonel hem de estetik açısından önemlilerdir. Bitkisel elemanlar fonksiyonel olarak görüntü kirliliğini ve gürültüyü engelleyip çocuklara mahremiyet sağlarken, estetik açıdan da güzel görüntüsüyle çocukların ilgisini çekmektedirler (Pouya vd., 2016). Bitkilerin insanlar üzerinde büyük psikolojik etkileri vardır. İnsanlarda rahatlık ve gizlilik duygusunu uyandırır.
İnsanlar ağaçların altında oturmaktan, onlara dayanmaktan, toprak yüzüne çıkan köklerinin üzerine oturmaktan, oturup konuşmak ve kitap okumaktan hoşlanırlar. Bitkiler okul bahçelerini güzelleştirirler. $\mathrm{Bu}$ nedenle bitkilerin kullanılmasında estetik değerler göz önünde tutulmalıdır (Yorgancllar, 2010).

Çocukların duyma, görme, koklama gibi duyuları ile algılamaları göz önünde tutularak; bitkiler biçim, renk, doku ve ölçü özelliklerine göre değerlendirilip doğru bir bitkilendirme tasarımı yapılmalıdır (Çelik ve ark., 2015).

Okul bahçesinde kullanımı uygun olan bitkiler güzel kokan aromatik bitkiler, bakıma çok ihtiyaç duymayan bitkiler, güneșten yararlanmaları için geniş yapraklı ağaçlar yerine küçük formlu, her mevsim farklı renk ve dokuya sahip bitkiler g gibi kriterlere göre ve engelli türleri göz önünde tutularak değişmektedir (Çizelge 2). Mesela görme engelli bir birey için aromatik kokulu bitkiler iyi yönlendiriciler ve vurgu elemanlarıdır.

Çizelge 2. Okul bahçesinde kullanımı uygun olan ve olmayan bitkiler

\begin{tabular}{cccc}
\hline Okul Bahçesinde Kullanımı Uygun Olan Bitkiler & Okul Bahçesinde Kullanımı Uygun Olmayan Bitkiler \\
\hline Türkçe isim & Latince İsim & Türkçe isim & Latince İsim \\
Erguvan & Cercis siliquastrum & Kadın tuzluğu & Berberis thunbergii \\
Ova akçaağacı & Acer campestre & Yayılıcı akasya & Robinia pseudoacacia \\
Leylak & Syringa vulgaris & Manisa lalesi & Anemone blanda \\
Cezayir menekșesi & Vinca minör & Çiğdem & Colchicum autumnale \\
Mavi ladin & Picea pungens & Süsen & Iris lutea \\
\hline
\end{tabular}

Dış mekânlar engelli çocukların iç dünyalarını dış dünya ile tamamlayabildiği ortamlardır. Engelli çocuklar, dış mekân kullanım alanlarındaki fiziki çevrenin bozukluğu nedeniyle sıkıntılar yaşamakta, bu nedenle zamanlarının çoğunu okul bahçelerinde ve 'iyileștirici' mekânlarda geçirmektedirler (Pouya ve ark., 2017).

$\mathrm{Bu}$ kavramsal bilgiler göz önünde tutularak okul bahçeleri tasarımlarına dikkat edilmelidir. Okul bahçesi erişilebilir, çocukların fiziksel aktivitelerini destekleyen, imkan sunan, sosyal ilişkilerini geliştirebilecekleri mekanlar olmalı onların sosyal hayata adapte olmalarına imkan sağlamalıdır. Yani okuldaki engelli bireylerin fiziksel ve sosyal olarak gelişimlerine katlı sağlayacak mekanlar tasarlanmalı, herkes için tasarım yapılmalıdır.

\section{Sonuç ve Tartışma}

Okul bahçelerinin toplumun birçok kısmında yer alamayan engelli çocukların gelişimi, topluma katılmaları için önemi büyüktür. Dünyadan okul bahçesi tasarımlarına bakıldığı zaman çocukların gelişimi ve doğayla iletişim kurmaları için belirli kriterler göz önüne alınarak tasarlandıkları ortaya çımaktadır.

Türkiye'de ki özel eğitim okul bahçelerinin tasarımlarında engelli çocukların ihtiyaçları göz ardı edilmekte ve gelişimine katkı sağlayacak düzenlemeler yapılmamaktadır. Özel eğitim okul bahçelerinin tasarımlarında ki sorunların çoğu, engelli çocukların engel türleri, ihtiyaç ve gereksinimleri göz önüne alınmadan tasarlanmasından kaynaklanmaktadır. Özel eğitim okul bahçelerini engelli çocukların kullanamaması sorununu ortadan kaldırmak için tasarımcıların engelli çocukları göz önünde tutarak, evrensel tasarım ilkeleri doğrultusunda tasarım yapmaları ve uygulanamaya geçirmeleri gerekmektedir. Devletin özel eğitim okul bahçelerini engelli çocukların kullanımına uygunluğu açısından incelemesi ve 
gerekli tasarım kriterleri belirlemesi de bu sorunun çözümü için büyük öneme sahiptir. Özel eğitim okul bahçelerinin engelli çocukların gelişimi için öneminin yanı sıra engelli bireylerin hayata tutunması için ailelerine, topluma ve devlete görevler düşmekte, onları ötekileștiren düzenlemeler, davranışlar, sözler ve tasarımlardan kaçınılmalı onların topluma kazandırılması için herkes elinden geleni yapmalıdır.

Çizelge 3. Okul bahçelerinin tasarımında dikkat edilmesi gereken konular

Okul Bahcelerinin Tasarımında Dikkat Edilmesi Gereken Konular

Ergonomi ve Kullanılabilirlik
Engelli bireylerin, engel türlerine göre ergonomik ölçüler göz önüne alarak tasarımlar yapılmalıdır. Bu kriterler göz önüne almadan yapılan tasarımlar kullanılabilir ve doğru tasarımlar değildir.

\begin{tabular}{|c|c|}
\hline $\begin{array}{l}\text { Okul Bahçelerinde } \\
\text { Fiziksel Hareketliliği } \\
\text { Destekleyen Mekan ve } \\
\text { Aktivitelerin } \\
\text { Tasarlanması } \\
\end{array}$ & $\begin{array}{l}\text { Okul bahçeleri engelli öğrencilerin engel türlerine göre fiziksel hareketliliğini sağlayacak şekilde } \\
\text { tasarlanmalıdır. Bu sayede öğrencilerin kasları, fiziksel hareketlilik becerileri gelişmekte bu da öğrencilere } \\
\text { psikolojik ve fiziksel olarak tatmin ve katkı sağlamaktadır. }\end{array}$ \\
\hline $\begin{array}{l}\text { Okul Bahçelerinde } \\
\text { Uygulama Bahçeleri ve } \\
\text { Doğa Eğitimi }\end{array}$ & $\begin{array}{l}\text { Engelli çocuklar için okul bahçeleri farklı doğal oluşumların bulunduğu,merak uyandırıcı sıkıştırılmış doğa } \\
\text { etkisi yaratan mekânlar olmalıdır. Bu nedenle okul bahçesinin engelli çocukların temel ihtiyaçlarını } \\
\text { karşılaması dıșında doğayla uyumlu çocukların engellerine yönelik terapi bahçeleri ve uygulama bahçeleri } \\
\text { barındırmalıdır. }\end{array}$ \\
\hline $\begin{array}{l}\text { Engelli Çocuklarin } \\
\text { Sosyalleşmelerine } \\
\text { Yönelik Tasarlanan } \\
\text { Aktiviteler }\end{array}$ & $\begin{array}{l}\text { Engelli çocukların sosyalleşmeleri,iletişim becerilerini geliştirmeleri, arkadaş edinmeleri için için önemli } \\
\text { araçlardan diğerleri uygulama bahçeleri, doğa eğitimi, hareketliliklerini destekleyen erişilebilir ve } \\
\text { ergonomik mekanlar yapılmasıdır. }\end{array}$ \\
\hline $\begin{array}{l}\text { Engelli Çocukların } \\
\text { Farklı Duyularına Hitap } \\
\text { Eden Tasarlanmış } \\
\text { Alanlar }\end{array}$ & $\begin{array}{l}\text { Çocukların engel türlerine yönelik doğal ortamlar oluşturulmalı ve donatılar kullanılmalıdır. Bu amaçla } \\
\text { bahçeler çocukların duyma, görme, koklama ve dokunma duyularıyla mekan farklarını algılayacağı şekilde } \\
\text { tasarlanabilir. Duyma duyusu için hareket edip ses çıkartan bitkiler dokunma duyusu için geniş ve dokulu } \\
\text { yapraklı bitkiler, koklama duyusu için güzel kokulu bitkiler; görme duyusu için kırmızı, turuncu ve sarı } \\
\text { renkli çiçekli bitki grupları kullanılmalıdır. Farklı sesleri kullanarak (su sesi, rüzgâr sesi gibi) çocuklar } \\
\text { üzerinde duyusal uyarım ve yönlendirme sağlanabilir. }\end{array}$ \\
\hline Bitki Seçimi & $\begin{array}{l}\text { Çocukların duyma, görme, koklama gibi duyuları ile algılamaları göz önünde tutularak; bitkiler biçim, } \\
\text { renk, doku ve ölçü özelliklerine göre değerlendirilip doğru bir bitkilendirme tasarımı yapılmalıdır. }\end{array}$ \\
\hline
\end{tabular}

Engelli çocuklar için okul bahçelesi tasarımlarında erișebilirlik ve ulaşabilirlik, ergonomi ve kullanılabilirlik, okul bahçelerinde fiziksel hareketliliği destekleyen mekan ve aktivitelerin tasarlanması, okul bahçelerinde uygulama bahçeleri ve doğa eğitimi, engelli çocukların sosyalleşmelerine yönelik tasarlanan aktiviteler, engelli çocukların farklı duyularına hitap eden tasarlanmış alanlar, bitki seçimi kriterleri göz önünde tutulmalıdır. Çocukların engel türleri ve bu kriterler doğrultusunda onların ihtiyaçlarına cevap verecek, psikolojik, fiziksel ve sosyal anlamda gelişimlerine katkı sağlayacak 'engelsiz okul bahçesi' tasarımları mümkündür.

\section{Çıkar çatışması}

Yazarlar arasında herhangi bir çıkar çatışması yoktur.

\section{Yazarların katkı beyanı}

EB: Araştırmanın literatür taraması, dünyadan örneklerinin incelenmesi ve belirlenmesi, araştırma amacının ortaya çıkması, araştırma taslağının ortaya çıkması(başlıklar, sıralamalar, makale akışı) ve tüm verilerin derlenerek son haline gelmesine kadar bütün aşamalarda yer almıştır. SP: Araştırmanın literatür belirlenmesi, araştırma taslağının ortaya çıkması (başlıklar, sıralamalar, makale akışı), araştırma başlıklarının ortaya koyulması ve düzenlenerek son haline gelmesine kadar ki aşamalarda yer almıştır.

\section{Kaynaklar}

ADA-Act Handbook (1991). Equal Environment Opportunity Comission and the U.S. Department of Justice, October

Aile ve Sosyal Politikalar Bakanlığı (2013). Erişilebilirlik İzleme ve Denetleme Yönetmeliği.

Akçamete, G.(1998). "Özel Gereksinimli Bireyler ve Özel Eğitim", Anadolu Üniversitesi Açıöğretim Fakültesi İlköğretim Öğretmenliği Lisans Tamamlama Programı Özel Eğitim Ders Kitabı. Eskișehir: Anadolu Üniversitesi Yayınlan, s. 3-10.

Aksu, Ö.V., \& Demirel, Ö. (2011). Trabzon Kenti ilköğretim okul bahçelerinde tasarım ve alan kullanımları. SDÜ Orman Fakültesi Dergisi, 12: 40-46.

Bekci, B.(2012). Fiziksel Engelli Kullanıcılar İçin En Uygun Ulaşım Akslarının Erişebilirlik Açıdan İrdelenmesi: Bartın Kenti Örneği. Bartın Orman Fakültesi Dergisi, Cilt:14, Özel Sayı, 26-36. 
Bezmez, D., \& Yardımcı, S., (2010). “Dönüşen Vatandaşlık Kurguları Çerçevesinde Sakat Hakları:

Kurumsal Yaklaşımlar ve Türkiye Örneği”, (Ed.) Filiz Kartal Yurttaşlık Tartışmaları: Yeni

Yaklaşımlar içinde (s.159-190), Ankara: TODAİE, NO:357

Bilsin, E., \& Bașbakkal, Z., (2014). Dünya'da ve Türkiye'de Engelli Çocuklar, Ege Üniversitesi Hemşirelik Fakültesi Dergisi, Cilt 30 , Sayı 2, Sayfalar 65 - 78

Çelik, A., Ender, E. \& Akdeniz Seyidoğlu, N. (2015). Engelsiz Parklarda Peyzaj Tasarımı. Tarım Bilimleri Araştırma Dergisi 8 (2), 05-11.

Doğan, A., (2019). Türkiye'de Özel Eğitim, Türk Eğitim Tarihi Kitabından, Ankara, Pegem Akademi.

Dönmez, B.N. (1992). Türk Milli Eğitim Sisteminde Özel Eğitimin Bugünkü Durumu ve Yeni Çalıșmalar, 1.Ulusal Özel Eğitim Kongresi, Ankara.

Ergül, C., Baydık, B., \& Demir, Ș. (2013). Özel eğitim öğretmen adaylarının ve öğretmenlerinin zihin engelliler öğretmenliği lisans programı yeterliklerine ilişkin görüşleri, Kuram ve Uygulamada Eğitim Bilimleri,13(1), 499-522.

Karakuș, M. K.,(2016). Engellilere Yönelik Kent Mobilyaları Üzerine İnceleme, Yüksek Lisans

MEB,(2012). Çocuk Gelişimi ve Eğitimi,Oyun Etkinliği 1.

Milli Eğitim Bakanlığı İstatistikleri (2019). Örgün Eğitim.

Özbaba, N., (2000). Okul Öncesi Eğitimcilerin ve Ailelerin Özel Eğitime Muhtaç Çocuklar ile Normal Çocukların Entegrasyonuna (Kaynaştırılmasına) Karșı Tutumları, Yüksek Lisans Tezi, Marmara Üniversitesi Eğitim Bilimleri Enstitüsü, İstanbul.

Özdemir. N., (2006). Türk Çocuk Oyunları.Cilt 1 /1. Ankara: Akçağ Yayınları

Özdemir, A., (2017). Engelsiz Oyun Alanları İçin Kapsayıcı Tasarım Yaklaşımı,Ege Mimarlık Dergisi,1.

Özsoy, Y., Özyürek, M., \& Eripek, S., (1996). Özel Eğitime Muhtaç Çocuklar Özel Eğitim Giriş, Ankara: Karatepe Yayınları, 1996, s. 3-25.

Öztürk, M., (2012). Türkiye'de Engelli Gerçeği Raporu, Canda Özür Olmaz Derneği, İstanbul.

Pehlivan, H. (2005). Oyun ve Öğrenme, Ankara: Anı Yayıncılık.

Pouya, S., Akyol Şatıroğlu, E. \& Demirel, Ö. (2016). Özel eğitim okul bahçesindeki alan kullanımlarının engelliler için uygunluğunun irdelenmesi, Uluslararası Hakemli Tasarım ve Mimarlık Dergisi, 9:60-72.

Pouya S., Bayramoğlu, E., \& Demirel, Ö. (2016).Doğa ile Uyumlu Fiziksel Engelli Çocuk Oyun Alanları, Süleyman Demirel Üniversitesi, Mimarlık Bilimleri ve Uygulamaları Dergisi.

Pouya, S., Bayramoğlu, E., \& Demirel, Ö. (2017). Bir engelli okulu bahçesi tasarım ana kararları: Doğan Cağlar ortopedik engelliler okulu, Kastamonu Univ.,Orman Fakültesi Dergisi, 17 (4): 682-690.

Resmi Gazete,(1997). Özel Eğitim Hakkında Kanun Hükmünde Kararname, Kanun numarası: 573.

Şat, N., \& Göver, T., (2017). Engelliler İçin Belediyelerin Erişilebilirlik Sorumlulukları: Çorum Engel Haritası Projesi, Yıl 10, Sayı 1, Haziran 2017, ss. 521-542

Tekin. H. H. (2019). "Engelli Üniversite Öğrencilerinin Eğitim Yaşamındaki Sorunları: Konya Örneği”, Manas Sosyal Araştırmalar D., 8 (2): 1531-1548.

TÜİK (2008). Türkiye İstatistik Kurumu Adrese Dayalı Nüfus Kayıt Sistemi, 2008. Nüfus Sayımı Sonuçları. Ankara: T.C. Başbakanlık Türkiye İstatistik Kurumu, Haber Bülteni.

Uslu, A.D. \& Güneș, M. (2017). Engelsiz kentler-herkes için erişilebilir kentler, Uluslararası Peyzaj Mimarlığı Araştırma Dergisi, E-ISSN: 2602-4322, 1 (2): 30-36

Uslu, A., \& Shakouri, N.,(2012). Engelli Çocuklara Dost Oyun Alanı ve Dıș Mekan Tasarımı,Erciyes Üniversitesi Fen Bilimleri Enstitüsü Dergisi, 28(5):367-374.

Yavuzer, H. (1993). Ana-Baba ve Çocuk, Remzi Kitapevi James D. MacConnell Award, (2019). Dr. J.P. Lord School

URL 1: Clark, M.D., (2019, Mayıs, 2020). Hamilton Lisesi, özel ihtiyaçları olan öğrencilerin benzersiz dıș mekan alanıyla bahçeye çıkmasına izin verir. 16 Temmuz 2020 tarihinde https://www.journalnews.com/news/local-education/hamilton-highschool-allows special-needs-students-garden-withunique-outdoor area/kyCMUxxZLKy8sp4fLEkpOK/

URL 2: Anonim, (2014, Kasım, 25). Horsham Özel Okulu Duyusal Bahçe. 12 Temmuz 2020 tarihinde https://a4le.org.au/awards/2014-awards/2014victorian-chapter-awards/vic-chapter-6-landscape -/-oudoor-learning-area/horsham-special-schoolsensory-garden adresinden erişildi.

URL 3: Hıckey, K., (2014, Eylül, 19). Horsham Özel Okulu baharı bir bahçe saldırısıyla karşılıyor.18 Temmuz 2020 tarihinde https://www.mailtimes.com.au/ story/2568742/horsham-special-school-welcomes -spring-with-a-garden-blitz/ adresinden erișildi.

URL 4: Anonim, (2017, Şubat, 6). Hokksund Ortaokulu. 25 Haziran 2020 tarihinde http://landezine.com/ index.php/2017/02/hokksund-middle-school-byostengen-bergo-landskapsarkitekter/ adresinden erişildi.

URL 5: Darland, (2018). JP Lord School. 2 Haziran 2020 tarihinde https://www.darland.com/jp-lord-school adresinden erișildi.

URL 6: BCDM, (2018). Dr. JP Lord School. 10 Haziran 2020 tarihinde https://www.bcdm.net/projects/ education /dr-j-p-lord-school/ adresinden erișildi. 